\title{
Silvia Gerschman* \\ Economia, Sociedade e Política na Construção de um Campo do Conhecimento: a Saúde Coletiva no Brasil
}

\begin{abstract}
Resumo: O objetivo do texto é mostrar que "Saúde Coletiva" constitui um novo campo de saber situado na interseção de vários saberes e práticas. Ressalta a contribuição específica da ciência política na conformação dessa nova "disciplina" acompanhando algumas vertentes fundadoras do pensamento político até a emergência das funções sociais do Estado. A autora chama atenção para a insuficiência da reflexão sobre Saúde Coletiva como política social quando se limita a discutir os aspectos operacionais de sua gestão, avaliação e controle sugerindo que se privilegie o exame da natureza do Estado que condiciona, amplia ou encolhe os limites e natureza das políticas sociais. Conclui afirmando a necessidade de uma formação disciplinar específica apoiada em disciplinas que tragam densidade teórica e analítica ao campo de conhecimento "Saúde Coletiva" como política social. Palavras-Chave: saúde coletiva, política social, Welfare State.

Abstract: The article deals with Health Care policy as a new field of knowledge and expertise, which is born under economic and societal transformations that lead capitalist State to assume the responsibility for social rights. The author's main objective is to call attention for the urge necessity of reshape a theoretical frame for understanding Health Care beyond operational procedures and rather as a social policy. Appealing to Political Science and its main currents of thought the author argues in defense of a more comprehensive academic approach in dealing with public health care policies. Keywords: health care, social policy, Welfare State.
\end{abstract}

O presente trabalho pretende refletir sobre o campo da Saúde Coletiva enquanto política social no Brasil e discutir as perspectivas que dão origem e sequência ao seu desenvolvimento. Ao modo da sociologia do conhecimento, destacaremos a associação entre o desenvolvimento do campo e as transformações societárias de uma época, o presente.

O processo de transformação e adequação da Saúde Coletiva, enquanto política social, remete não apenas ao campo cognitivo das ciências sociais e seus enfoques teórico-metodológicos, mas fundamentalmente à identificação de transformações do Estado, das políticas e da economia que afetaram a própria Saúde

Socióloga e doutora em Ciências Sociais pela Universidade Estadual de Campinas (1994). É professora da PosGraduação em Saúde Pública da Escola Nacional de Saúde Pública da Fundação Oswaldo Cruz e pesquisadora titula da mesma. Endereço Postal: Fundação Oswaldo Cruz, Escola Nacional de Saúde Pública, Departamento de Administração e Planejamento em Saúde. Leopoldo Bulhões 1480/ 7º. Andar, Manguinhos. gerschma@terra.com.br. 

Coletiva nos anos recentes ${ }^{1}$. O objetivo é refletir sobre um campo específico e fundamental de questões teórico-metodológicas. Trata-se da análise política no campo da Saúde Coletiva à luz de uma discussão teórica sobre o Estado sob suas várias formas, com especial ênfase nos Welfare States.

Ainda que a preocupação não seja o campo da Saúde Coletiva em si mesmo, por ser este extenso e multidisciplinar, parece-me obrigatório considerar como ponto de partida originário da denominação Saúde Coletiva a reflexão das ciências sociais com foco na saúde.

\section{As Ciências Sociais e a Saúde Coletiva}

Constituem-se em marco referencial do campo das Ciências Sociais em Saúde os trabalhos pioneiros da década de 1970 e 1980, do século XX, amplamente divulgados e citados na maioria dos estudos sobre o tema. Autores como Arouca, Belmartino, Berlinguer, Duarte, Cordeiro, Donangelo, Fleury, Foucault, Garcia, Gentile de Melo, Luz e tantos outros marcaram a introdução das Ciências Sociais no campo da Saúde. Tratava-se, na época, de área de conhecimento profundamente esfacelada; de uma parte, as Ciências Sociais interpelavam a saúde apenas como ciência aplicada e, portanto, com um status inferior; de outra parte, as próprias Ciências Sociais em Saúde enfrentavam dificuldade "externa", pois visavam "... oferecer uma contraposição e contrapeso ao establishment da Biomedicina e sua continuada fidelidade ao paradigma empiro-universalista" (DUARTE, 1997, p.75).

A expectativa era abrir um campo que fosse além dos estreitos limites da compreensão da Saúde no marco epistêmico das ciências assim chamadas "duras", para as quais o corpo doente é entendido enquanto órgão(s) impedido(s) de produzir as suas funções "normais". Nas diversas visitas das Ciências Sociais à Saúde, o "oIhar biomédico sobre os corpos" torna-se objeto de uma reflexão humanizada. A doença é compreendida enquanto processo multideterminado pela própria existência individual e social.

Contudo, segundo Duarte (1997), as próprias Ciências Sociais são sujeitas a uma tensão epistêmica constitutiva entre os "pólos cognitivos e interpretativos". De uma parte, o potencial empírico universalizante; de outra, a "espessura romântica" e hermenêutica da experiência singular. Oposição que se expressa entre objetivismo e subjetivismo e a tendência à quantificação e as tendências voltadas à análise qualitativa. Tensão que, por contiguidade, acontece na Saúde Coletiva, seja pela própria tradição das Ciências Sociais, seja por seu próprio objeto da Saúde Coletiva, que é ao mesmo tempo individual e social.

As Ciências Sociais, por sua vez, enfrentaram analítica e teoricamente um mundo em profundas mudanças, tanto econômicas quanto políticas, que não poderiam ser consideradas auspiciosas para a expansão e crescimento das sociedades do final do século XX. A complexificação de ambas, sociedade e saúde, se traduziram na multiplicação de esferas do saber e abordagens no interior das Ciências Sociais

\footnotetext{
i O percurso teórico desenvolvido neste ensaio corresponde à disciplina Conceitos Básicos em Teoria das Políticas Públicas, por mim ministrada nos anos que vão de 1997 a 2007. Com este artigo me proponho a dar uma forma mais estruturada ao que considero o enfoque teórico conceitual da Saúde Coletiva.
} 
e da Saúde Coletiva, na tentativa da compreensão dos retrocessos verificados nas configurações das economias e das políticas na transição dos governos do "Bem Estar social" após a Segunda Guerra Mundial para os governos do "ajuste econômico" do final do século XX.

O campo da Saúde Coletiva, que se constitui próximo ao fim das "sociedades da abundância" europeias, nos anos setenta, é fortemente influenciado no Brasil pela transposição, por vezes mecânica, das abordagens marxistas da economia e da sociedade predominantes na conjuntura das social-democracias europeias. Ainda que estes enfoques se mostrassem extremamente precários para subverter a ordem biomédica, tiveram o mérito de constatar a falência dos pressupostos da biomedicina para dar conta do corpo doente enquanto totalidade biológica, social, psicológica e espiritual, falência evidenciada pelo aparecimento de novas doenças e as suas relações com a sociedade e a cultura, como por exemplo a AIDS, e o reaparecimento de velhas epidemias resultantes de condições econômicas de extrema carência.

Observa-se que, com todos os avanços tecnológicos que se aceleraram nas últimas três décadas, o desemprego, a exclusão social, a marginalidade e as doenças que acompanham as mazelas da sociedade pós-moderna cresceram e se expandiram assustadoramente, fenômenos que o conhecimento acumulado é incapaz de explicar. Novos objetos e novas áreas com uma multiplicidade de abordagens se reproduzem como cogumelos no campo da Saúde Coletiva.

Na base desta proliferação, devem-se situar, de uma parte, as transformações aludidas do mundo moderno e de outra, a expansão de enfoques epistêmicos compreensivos capazes de abordar a saúde enquanto epifenômeno do modo de viver na sociedade da exacerbação do mercado. A noção de "biopolítica" (Foucault) é uma referência central na compreensão destas duas ordens, a do biológico e a das mudanças sociais, econômicas e políticas que se operaram na metade do século $X X$, que se caracterizaram pelo papel conferido ao Estado e ao governo e que perduraram até os anos iniciais do século XXI. Estas mudanças resultam da ênfase dada ao neoliberalismo como ordenação indiscutível da economia política, da sociedade e do Estado. Assim, a racionalidade moderna plasmada por e pelo mercado torna-se ideologia, dever ser do mundo moderno pela ação onipresente do mercado. A única "autolimitação da razão governamental" é a do liberalismo, não interferir no mercado e deixar este agir. No dizer do autor:

Parece-me, contudo, que a análise da biopolítica só poderá ser feita quando se compreender o regime geral dessa razão governamental... esse regime geral que podemos chamar de questão de verdade - antes de mais nada da verdade econômica no interior da razão governamental -, e, por conseguinte, se compreender bem o que está em causa nesse regime que é o liberalismo, o qual se opõe à razão de Estado, ou antes [a] modifica fundamentalmente sem talvez questionar seus fundamentos. Só depois que soubermos o que era esse regime governamental chamado liberalismo é que poderemos, parece-me, apreender o que é a biopolítica (FOUCAULT, 1979, p. 30). 
A questão de Foucault que permanece para nós, enunciada nesta aula de 10 de Janeiro de 1979, é a de compreender o caminho a seguir para analisar a saúde enquanto política social de governo. Se todas as políticas de governo permanecem sendo implementadas no espaço limitado da razão de Estado, ou seja, no espaço da assistência social, em que a questão social fica reduzida às alternativas dadas nos contextos governamentais do presente, cabe perguntar: como detectar espaços possíveis de atuação e de que maneira poderíamos interferir nos mesmos?

\section{A Ciência Política, as Políticas Sociais e a Saúde Coletiva}

A contribuição da Ciência Política à Saúde é das mais recentes abordagens incorporadas ao campo e tem operado em diversos planos de análise. Trata-se de campo conceitual específico e diferenciado de outros saberes. A análise política da saúde coletiva nos remete à necessidade de uma formação disciplinar específica diferenciada da gestão de sistemas e serviços de saúde.

Duas vertentes de Ciência Política têm se incorporado à análise da saúde. Uma de caráter mais analítico, referida ao Estado, à economia e a processos de formulação e implementação de políticas sociais. Diversos enfoques teóricos marcam esta abordagem da política de saúde e basicamente se relacionam com o caráter do Estado sob o qual a política social, e especificamente a de saúde, é definida. O Estado welfariano ocidental constitui um marco para a análise da política pública sob a perspectiva de uma particular modalidade de relação Estado-sociedade e do direito de cidadania como contrapartida desta relação: a constituição da esfera pública como o espaço de exercício da cidadania por meio dos direitos sociais.

Uma outra vertente refere-se a aspectos mais operacionais, orientada para análise e avaliação de políticas e programas de saúde. Em que medida a implementação e formulação de políticas se diferenciam, seja por correspondência, aproximação ou reformulação; a existência de diversidade de modelos e perfis de intervenção estatal/privada; como agências governamentais e atores interagem no processo de formulação e implementação; estratégias de interação dos atores; os mecanismos decisórios utilizados pelas instituições responsáveis; as inter-relações entre essas variáveis (atores e estratégias) e as variáveis externas que influenciam esses processos (VIANNA, 1996,1997). Ainda num sentido restrito, a avaliação das políticas e/ou programas pode gerar informações quantitativas sobre aspectos econômicos, administrativos e/ou gerenciais, assim como sobre o impacto da aplicação de programas e políticas através da utilização de métodos empíricos para chegar a afirmações causais sobre a eficácia das mesmas. A utilização de métodos permite imputações causais sobre a eficácia das políticas.

Sobre a primeira vertente que vai constituir o eixo central do nosso esforço teórico, importa o diálogo com as teorias compreensivas sobre o Estado e as políticas públicas que nele se inscrevem. A que Estado e a que governo estamos nos referindo? A referência central é sempre ao Estado e à políticas de saúde nos governos do presente, aos quais denomino governos da restauração liberal. Mas só será possível compreender o presente se referido ao passado, olhado sob uma perspectiva teórico - conceitual que o ilumine e que se torne capaz de contribuir para a compreensão das políticas de saúde enquanto políticas sociais no presente. 
O Estado e o Pensamento Liberal Clássico

O Estado liberal nas suas origens destrói seus precedentes, o Estado feudal e o Estado do absolutismo. A fundação de uma nova sociedade e do Estado nela imbricado se apoia no pensamento liberal que recusa taxativamente a sociedade, a economia e a política dos antigos Estados feudais ligados à terra e ao trabalho artesanal e dos estados monárquicos ligados às formas da sociedade comercial dos séculos XVII, XVIII e XIX. É pois, fundamental, compreender as categorias com as quais se desmontam os princípios do passado e se elaboram novas formas de sociabilidade que passam pelo crescimento e fixação do mundo moderno.

Quando Benjamin Constant elabora seus Princípios Constitucionais de Governo, funda as bases da forma liberal de governo. Quando James Mill escreve o Essay on Government, justifica fortemente o Estado liberal como aquele que provê grande felicidade para a maioria. Quando Marx elabora os fundamentos críticos da sociedade capitalista e sua forma Estado - me refiro especificamente ao Manifesto Comunista - propõe-se a desconstruir a teia do pensamento liberal sobre o Estado, mostrar que esta é a base da própria constituição do Estado liberal e explicá-lo enquanto forma política correspondente à sociedade de mercado. Conclui que o Estado, e seus aparelhos no capitalismo, não é mais do que "o comitê de negócios da burguesia". O Manifesto é um documento de militância política e por este motivo é contundente, não deixando por conta do leitor nenhuma brecha na qual possa crescer a semente da dúvida em relação ao Estado no capitalismo. Ainda não sendo um texto analítico do Estado no capitalismo, o Manifesto gera novos parâmetros para a compreensão do Estado Capitalista que são de significativa importância para a análise das políticas sociais e as de saúde no capitalismo. A obra de Max Weber, Economia e Sociedade, elabora modelos de economia e de relações sociais que contrapõem civilizações tradicionais ao que chama de modernas sociedades do capitalismo. O último dos autores tratados neste eixo temático sobre o Estado será Polanyi, que escreve na primeira metade do século XX e para quem a associação entre Estado e mercado no capitalismo é de mutua imbricação. O Estado não pode deixar de interferir no mercado já que, se assim não fosse, as forças do mercado se tornariam tão destrutivas que liquidariam com a sociedade e com o próprio mercado. Se o Estado abandonasse o seu papel de guardião da existência e reprodução do mercado e da sociedade capitalista, estaria se abstendo das suas atribuições legítimas. Considera o autor que interferir no mercado é indispensável não apenas para a sobrevivência do mercado, mas principalmente para a própria sobrevivência da civilização. O mercado liberado a si mesmo faz do trabalho da terra e do dinheiro mercadorias sujeitas à oferta e à demanda, e não mais condições necessárias e indispensáveis para a sobrevivência dos homens na sociedade. Não poderiam estas ficar sujeitas apenas às leis do mercado.

A tensão permanente entre políticas sociais e liberalismo nas sociedades do presente é caudatária da leitura marxiana sobre a sociedade e o Estado capitalista. Até que ponto uma política social que se torne também política econômica poderá sobreviver sob o liberalismo e, inversamente, até que ponto políticas de assistência social contribuiriam para a reprodução de formas societárias capitalistas? Para compreender estas formulações na sua complexidade, cumpre refletir sobre um 

campo de conhecimento teórico-metodológico que, de uma parte, dá densidade e existência ao Estado capitalista e de outra, subsidia o estudo das políticas sociais e de saúde no seio das relações Estado-Sociedade na contemporaneidade.

O Estado idealizado por Benjamin Constant é aquele capaz de restaurar a ordem na França do fim do século XVIII, que num lapso de apenas 40 anos atravessou nove mudanças de regime político pelas quais operou-se a transição do velho regime para o novo. A grande instabilidade política na França desse período corresponde ao estabelecimento de um processo econômico de transformação capitalista pujante e de intensas contradições. A assimilação às mudanças no emprego e os próprios processos produtivos implicados exigiam transformações culturais e institucionais de grande escala e de longo prazo. De fato, enquanto estas mudanças não acontecem com a mesma rapidez que os processos econômicos, há um despejo permanente dos refugos da sociedade para os braços da pobreza extrema. Escritos da época descrevem as misérias geradas pelas transformações econômicas capitalistas e, embora esta literatura seja mais difundida na Inglaterra, onde o processo de industrialização começou primeiro e se processou de forma mais virulenta, na Alemanha e na França existiam também movimentos libertários, literatura e estudos sobre as condições da nova classe operária.

Os pensadores liberais enfrentavam estas transformações e aspiravam, no plano do Estado e do governo, produzir uma forma política adequada à nova sociedade e que protegesse a nação e o governo dos "desmandos que o povo poderia cometer contra a nação e contra si mesmo". A desordem do povo nas ruas e a participação inconsequente desta nova classe média, de operários e de miseráveis, significava uma ameaça à vida política que poria em perigo a existência do governo da sociedade. A ordem política liberal era destinada, assim, a instituir o governo sobre todos, capaz de se impor ao conflito entre particulares e estabelecer o governo da maioria.

Para Constant, existem apenas dois poderes: um ilegítimo, a força, e outro, a vontade da maioria. O poder que se converte em vontade geral, em interesse da maioria, é o poder delegado a alguns pela vontade de todos. A soberania ilimitada é ruinosa, independentemente de quem a exerça. No caso de ser outorgada ao povo, implicaria em perda da liberdade. Os cidadãos possuem direitos independentes de qualquer autoridade social ou política e a violação destes é ilegítima. A soberania do povo, não é ilimitada; é circunscrita pelos limites da justiça e dos direitos dos indivíduos. O povo não tem o direito de atentar contra a liberdade de opinião, a liberdade religiosa e as garantias judiciais. Nenhum déspota, nenhuma assembleia, pode exercer um direito semelhante alegando que lhe foi conferido pelo povo.Todo despotismo é ilegítimo.

A solução dos conflitos políticos permanentes, da ameaça das classes emergentes e o restabelecimento da ordem seria tarefa da "república monárquica", a melhor forma de governo para se chegar à estabilidade política na França. A monarquia constitucional inglesa é sua fonte de inspiração política. A arte das constituições é permitir que os homens honestos ocupem seu lugar sem que para isso seja necessário perturbar a paz pública; como ocorreu com a Revolução Francesa de 1789, mas sem suas sequelas. 
Por que a república monárquica inglesa seria a forma mais adequada de governo para Constant? Por inspirar uma forma mista de governo na qual se combina a monarquia hereditária e/ou eleita com as Câmaras formadas por representantes eleitos através de voto censitário. Neste modelo, cada um fica nos limites das suas respectivas atribuições. Um grande defeito de todas as Constituições é não deixar aos homens poderosos alternativas entre o poder ou a morte. Uma monarquia constitucional resolveria esse problema, já que, após a destituição do poder, os funcionários de governo se reintegrariam à classe dos demais cidadãos. Condição própria dos ministros, assembleias e tribunais, mas nunca do monarca, que pode e deve ser inviolável. As repúblicas são levadas a responsabilizar o poder supremo e por isto tornam a responsabilidade ilusória. Nunca se deve pensar em exigir responsabilidade de homens cuja queda interrompa a ação do Estado - externa e/ ou interna. Uma condição indispensável para que a responsabilidade seja efetiva é separar o poder executivo do poder supremo. Na Inglaterra, o direito de resguardar a ordem vigente era atribuição do poder real, enquanto o direito de propor regulamentações sobre novas situações era atribuição do poder ministerial.

Compete ao monarca o direito de conceder graça, direito de uma natureza quase divina que repara os erros da justiça humana e seus rigores demasiado inflexíveis que Constant considera erros. Todo poder arbitrário se opõe à natureza do poder real, pois por natureza a imparcialidade e a virtude são atributos do monarca. Para o autor, há situações que destroem a possibilidade de tranquilidade e a esperança de liberdade, quando a arbitrariedade se converte em atributo quer da autoridade ministerial, quer do próprio rei que, ao deixar de ser neutro, se torna uma espécie de ministro mais temido porque une à inviolabilidade atribuições que nunca deveria possuir.

A ideia de Constant é estabelecer uma ordem política que perdure e não possa ser quebrada nem pelo povo, nem pelos governantes. A Constituição garantiria o Estado de direito em que predomina a vontade geral. O poder que se converte em vontade geral é o poder delegado a alguns pela vontade de todos e este poder somente poderá contemplar a vontade geral, que expressa a diversidade de interesses presentes numa forma combinada de governo. Na prática, a monarquia constitucional deve prover da sustentação necessária ao rei para que ele paire sobre a sociedade e seja juiz inconteste. Este papel é exercido por um corpo político intermediário que delibera, exerce as funções administrativas e de governo e desempenha o papel de mediador entre o rei e a sociedade. Na Inglaterra é a Câmara dos Pares. Nomeia-se par um simples cidadão que goza dos mesmos privilégios legais que o mais antigo dos pares. As classes secundárias das primeiras Casas da Inglaterra penetram na massa do povo e são um laço entre os pares e a nação; assim, a função da Câmara dos Pares é a de ser um laço entre a nação e o trono.

Se o que se pretende é gozar completamente dos benefícios do governo representativo, há que se adotar a eleição direta. Mas a eleição direta não significa que qualquer um pode votar e/ou ser candidato. Vários capítulos dos Princípios Constitucionais são dedicados à compreensão do que deva ser eleição direta, quem poderia se candidatar, quem poderia votar, e com que restrições. 
A eleição direta - dispensa Colégios Eleitorais - é também importante porque vincula os proprietários às suas propriedades, nelas fixando as raízes de sua vida. Além do que, somente a propriedade assegura o ócio necessário à capacitação do homem para o exercício dos direitos políticos. Quando os não proprietários têm direitos políticos, atuam por conta do seu impulso e destroem a sociedade; ou são movidos pelos que estão no poder e estão a serviço da tirania; ou ainda, são candidatos ao poder daqueles que os manipulam e são instrumentos de facções. Por esses motivos, devem ser estabelecidas condições de propriedade tanto para os eleitores como para os elegíveis. A inclusão dos não proprietários entre os legisladores despertará inquietação nos proprietários e dificultará a aplicação da legislação. Para Benjamin Constant, as faltas cometidas pelos proprietários durante a Revolução Francesa foram produto do medo e pressão que sentiram dos não-proprietários investidos de poder.

A propriedade territorial e a propriedade industrial não estão no mesmo plano. A constituição elaborada pelo autor reconhece este princípio. É sobre as vantagens da propriedade territorial que se fundamenta o espírito preservador necessário às associações políticas. A propriedade industrial propicia benefícios econômicos, mas não proporciona regularidade à vida sendo mais artificial e menos inalterável que a propriedade territorial. Uma exploração agrícola ${ }^{2}$ é uma pátria em miniatura. Quanto aos que não têm sua indústria e estão entregues a uma ocupação mecânica, ficam privados de todo meio para se instruir e podem levar o Estado a erros. "A esses homens há que respeitá-los, protegê-los contra todo vexame por parte dos ricos, mas não levá-los a um ambiente novo onde a sua cooperação seria inútil, suas paixões ameaçadoras e sua ignorância perigosa."(CONSTANT,1989, p. 125).

A propriedade intelectual é considerada por Constant como desvantagem e o cientista, um mau eleitor. Cada ciência tem uma direção exclusivista que se torna perigosa nos assuntos políticos. O equilíbrio encontra-se apenas na propriedade. Somente a propriedade assegura o ócio necessário à capacitação do homem para o exercício dos direitos políticos

James Mill, contemporâneo de Benjamin Constant, no seu Essay of Government afirma que o tema do governo da sociedade é o da adaptação dos meios aos fins, mas esta não é uma questão clara, já que os meios e os fins nunca foram analisados. O fim do governo consiste "na grande felicidade para um grande número".

A maioria das atividades do homem é determinada pelo prazer e pela dor; prazer e felicidade são alcançados quando os prazeres são grandes e as dores são pequenas. Mas há um outro princípio anterior ao governo: é o crescimento dos negócios o que proporciona o maior prazer aos homens e contribui para diminuir a dor; por isso, grande parte de nosso prazer reside na posse de propriedade. Não há dúvida de que a causa primária do governo é que a natureza não produz espontaneamente todos os objetos de nosso desejo, já que se o fizesse não haveria motivo

${ }^{2}$ Em adição posterior, Constant conferiu aos "fabricantes" direitos eleitorais similares aos dos proprietários territoriais. A burguesia se impôs a seu pensar amadurecido. 

No caso, os fins podem ser obtidos por meio do governo como um meio de distribuir, ainda que de forma menos desejável, o que for possível para um grande número de membros da comunidade.

Todas as dificuldades das questões de governo residem em refrear os meios em cujas mãos é depositado o poder necessário para proteger todos do mau uso deste. Acontece que os membros do governo estão sujeito também ao abuso de poder.

Existem para Mill três modalidades de governo sobre as quais pode se supor que o poder de proteção da comunidade é passível de ser exercido. O governo pode ser depositado nas mãos de muitos homens, de poucos homens ou de um homem. Estas três modalidades correspondem respectivamente à democracia, à aristocracia e à monarquia.

Poder é um meio para um fim, o que as pessoas chamam de prazer e eliminação da dor. O grande instrumento para consegui-lo é a ação de outro homem. Poder no seu significado pleno significa os meios para chegar com segurança à conformidade entre o desejo de um homem e os atos dos outros homens. Mill afirma que não tem se dado a devida importância a este fato e os assuntos (negócios) de governo têm sido mal entendidos. Ora, o monarca absoluto também ele usará o poder para seu prazer próprio.

O prazer parece ser um instrumento mais débil de obediência se comparado com a dor, o supremo meio coercivo. Isto significa um poder ilimitado de infringir dor, de coagir. Vemos assim que nenhuma das três formas de governo é adequada para a finalidade de governo: a democracia, por incapacidade política, e as outras, por serem despóticas. Na Inglaterra, deve-se frisar em concordância com muitos outros escritores, um deles Benjamin Constant, que a imperfeição de cada uma das três formas de governo evidencia que a finalidade de governo pode ser alcançada somente através da união das três formas de governo. Esta parte da teoria de Mill é conhecida como "doutrina dos equilíbrios constitucionais". Trata-se de uma união de desejos que permite que as três partes possam interagir adequadamente. É a conhecida teoria do equilíbrio entre as partes que conformam o governo. Pode se supor que quando o governo é composto pela monarquia, aristocracia e democracia, como na Inglaterra, uma se equilibra com a outra; mas também existe o perigo de duas delas se combinarem contra a terceira.

Para o autor, a grande descoberta dos tempos modernos é o sistema representativo exigindo que o corpo representativo desenvolva atribuições específicas para a salvaguarda do bom governo. Estas são: o mandato do representante deve ser temporário; as eleições devem ser periódicas e majoritárias; os eleitores devem ser homens com mais de 40 anos, proprietários ou com ocupação. O corpo representativo que fiscaliza deve ter o poder suficiente para examinar os assuntos de governo e deve ter uma identidade de interesses com a comunidade. Do contrário, pode fazer mal uso deste poder. Deve-se ainda considerar o grau de poder necessário para o bom desempenho da função.

Quem escolhe? Se um pequeno número escolhe o representante, pode responder ou promover os interesses de um número pequeno; neste caso, todos os 

os benefícios do sistema representativo também se perdem quando o interesse de um corpo eleitoral não é o mesmo que o da comunidade, que necessariamente teriam que incluir os interesses de outros indivíduos, mulheres, crianças. Para Mill, a classe média é a liderança natural das maiorias populares na sociedade inglesa. Consequentemente, os representantes escolhidos pelo voto do povo vão acompanhar os interesses da maioria da comunidade, ou seja, da classe média e assim será porque é do interesse de todos.

Pela mão destes autores seminais do liberalismo e formuladores dos princípios políticos de governo do Estado capitalista moderno é possível compreender o contexto sócio-político e histórico no qual o liberalismo finca suas raízes. A Revolução Francesa como fenômeno social e político emergente das transformações capitalistas e o assentamento de uma nova classe, a burguesia, são paralelos ao declínio da nobreza, que vivia em conflito permanente com as classes emergentes. Diferentemente, o processo de transformação social e econômico capitalista na Inglaterra resulta no estabelecimento do governo compartilhado entre o monarca, a nobreza e a burguesia através das Câmaras que comportam a divisão de poderes e um certo equilíbrio político que se caracteriza pela mistura entre as três formas de governo: monarquia, aristocracia e democracia.

As questões que neste momento histórico-político iluminam o pensamento liberal e as sociedades europeias são o estabelecimento das liberdades individuais e, pouco mais tarde, os direitos políticos. Observa-se que para as doutrinas liberais o governo existe apenas para garantir a posse da terra, a realização do lucro (mercado) e a felicidade de um grande número, especialmente daqueles cidadãos proprietários aptos para votar e serem votados. As políticas sociais não são tematizadas, muito pelo contrário. Na época, a revolução industrial se constitui sob a forma de um acelerado processo de desenvolvimento econômico que deixou na miséria aqueles que não tinham condições de se adequar às mudanças operadas no processo produtivo. Esses excedentes sociais ficariam ausentes da reflexão liberal sobre o Estado que percebe a sociedade como uma associação de indivíduos livres aos quais não cabia ao Estado prover o bem-estar. A quem não fosse cidadão/proprietário e não conseguisse no mercado a satisfação das suas necessidades, restava viver na miséria. Não cabia ao Estado melhorar as condições de trabalho, prover o alívio da pobreza, ou bem-estar dos indivíduos.

\section{A Análise Teórico-Crítica do Estado no Capitalismo}

Os Estados de Bem-Estar da segunda metade do século XX se sustentam sobre abordagens teóricas bem diferenciadas do liberalismo. Alguns autores dos séculos XIX e XX são centrais para a compreensão dos Estados de Bem-Estar Social constituídos após a Segunda Guerra. Serão considerados nesta seção: os estudos de Marx sobre o Estado no capitalismo; de Weber sobre o exercício da dominação nas sociedades tradicionais e modernas e de Polanyi sobre o papel e ação das instituições e do Estado sobre o mercado. Compreender o Estado no capitalismo avançado, enquanto instituição direcionada ao ordenamento e reprodução de relações sociais de produção, remete às transformações econômicas, sociais e políticas da história destes séculos e à visão que o pensamento social tem das mesmas. 
O ponto de partida para Marx é a produção material e o fato de que esta nunca existiu fora da sociedade; os indivíduos produzem em sociedade. Após a sociedade comunal na qual a terra a todos pertencia e todos a usufruíam, a organização da sociedade, qualquer que esta seja, leva a ordens sociais e políticas distintas e opostas. Assim as relações sociais de produção que comportam as modalidades pelas quais os homens se relacionam social e economicamente ao longo da história reproduzem a polaridade entre os diversos agentes de produção - opressores e oprimidos:

homem livre e escravo, patrício e plebeu, senhor e servo, mestre de corporação e companheiro, numa palavra opressor e oprimido permaneceram em constante oposição um ao outro, levada a efeito numa guerra ininterrupta (MARX,1978, p. 94).

A ideia de guerra está presente em Marx e diferentemente dos pensadores liberais já não pela conquista das liberdades, mas pelo exercício da dominação em qualquer e em todas as formas históricas de produção e sob todas as formas sociais e políticas correspondentes. A diferença se situa na aceleração da acumulação e da tecnologia que caracterizam o capitalismo moderno: a conquista de territórios desconhecidos, o desenvolvimento da navegação e das trocas comerciais e, por fim, a indústria.

Neste processo de transformação dos modos de produção com o comércio primeiro, e a manufatura depois, o trabalho e seu produto, a mercadoria, constituem as categorias centrais do modo de produção capitalista que adquirem concretude quando se opera a sua realização no mercado. No capitalismo, a mercadoria contém o trabalho necessário para sua produção que não é dado pelo valor de uso da mesma e sim pelo seu valor de troca. O valor de troca supõe o custo do trabalho despendido na sua produção, mas para Marx este valor é ilusório na medida em que a mercadoria não equivale à quantidade de trabalho necessário para produzila; se assim fosse, não haveria lucro e também não haveria mercado.

O que caracteriza o modo de produção capitalista é a garantia que ao cabo do processo de produção -incluindo seus componentes (investimento do capitalista, salário do trabalhador, desgaste dos instrumentos de trabalho/maquinarias do capitalista ) - as mercadorias poderão ser vendidas no mercado por um valor maior do que o valor do trabalho que elas contém, ou seja, a própria produção de mercadorias garante o seu lucro no mercado. O lucro obtido no processo de comercialização de mercadorias corresponde ao que Marx chama de mais valia, aquela parte do trabalho não remunerada que fica para o capital.

Substituindo os termos trabalhador e capitalista pelos de operário e burguês, reaparecem os personagens centrais da idéia de classes sociais antagônicas nas sociedades capitalistas modernas e, em sendo antagônicas, alimentam o estado de guerra entre opressores e oprimidos. Enquanto se torna classe universal, a burguesia gera um estado de beligerância permanente com a classe antagônica, o proletariado, e de transformações permanentes nas forças produtivas, nos meios de produção e nas relações sociais de produção, as quais acabam por subverter os modos de vida e os valores existentes: 
Tudo o que era sólido se evapora no ar, tudo o que era sagrado é profanado (...) e por fim o homem é obrigado a encarar com serenidade suas verdadeiras condições de vida e suas relações com a espécie (MARX, 1978, p.96 ).

É interessante assinalar que quando Marx se refere à moderna sociedade capitalista, ressalta repetidas vezes o caráter global da mesma (idem, ps. 94, 95, 97) que se caracteriza pela enorme expansão dos mercados que a leva a "a burguesia a invadir todo o globo", "dar um caráter cosmopolita à produção e ao consumo", "submeter o campo à cidade", "suprimir a dispersão da população", "concentrar a propriedade", "à centralização da política", que estabeleceu o governo da burguesia e "unificou províncias independentes reunindo-as em uma só nação". E ainda:

...a burguesia desde o estabelecimento da indústria moderna e do mercado mundial, conquistou finalmente a soberania política no Estado representativo moderno. O Governo do Estado moderno é apenas um comitê para gerir os negócios comuns de toda a burguesia ( MARX,1978, p.96).

A ideia da defesa das liberdades individuais enquanto felicidade do homem, para Constant, ou para a obtenção do prazer, em Mill, existe apenas em Marx, para a proteção das atividades de acumulação que dão origem a esta nova classe, a burguesia, e que a tornam universal. O Estado não é apenas de uma burguesia particular, mas de toda a burguesia enquanto classe universal. Para Marx, o Estado expressa apenas a supremacia política da ordem correspondente às relações sociais de produção vigentes em cada sociedade. No modo de produção capitalista, o Estado é o da dominação burguesa. Nas situações históricas em que a burguesia conquistou o poder, estabeleceu como forma predominante das relações sociais de produção a propriedade privada dos meios de produção e a sua contrapartida, a exploração do trabalho dos não-proprietários.

Nos governos da burguesia, os mercados continuam a crescer permanentemente. Nestes, o princípio que rege a economia é a oferta baseada no consumo dos agentes sociais que geram demanda que, por sua vez, estimula a oferta, que aquece a produção, fechando assim o círculo virtuoso oferta/demanda-produção/ consumo. Nesta espiral, o mercado se distancia cada vez mais das necessidades reais do homem e seu papel é ser indutor de consumo.

Ao tempo em que as necessidades próprias do homem se tornam cada vez mais inalcançáveis para aqueles que vivem da remuneração do trabalho - os operários -, a burguesia usufrui de um consumo crescente que se satisfaz com novos produtos, novas tecnologias, altos preços e exclusividade. A economia política do Estado capitalista se sustenta e se reproduz na ideia de uma generalizada e indiscutível "existência racional" baseada em um alto padrão de consumo.

$\mathrm{Na}$ concepção marxista, o Estado enquanto agente político da dominação da burguesia, assim como no liberalismo - ainda que sob leituras opostas -, não poderia agir como guardião de direitos sociais de cidadania nem se responsabilizar 

pela efetivação destes direitos, já que su função do Estado é a reprodução do capital e da hegemonia burguesa.

Os direitos sociais de cidadania - saúde, educação, moradia - são tardios na historia social da humanidade, datam do século XX, e surgem no contexto social e político de pós-guerra e como resultado da luta social e política da classe operária, da crescente importância dos partidos social-democratas na Europa, da existência do comunismo na União Soviética e do crescimento da militância política de esquerda. Paradoxalmente nesta mesma época, a responsabilização do Estado pela obrigatoriedade de políticas direcionadas ao bem-estar da sociedade passa a ser considerada central às atividades do Estado como condição necessária ao próprio desenvolvimento do capitalismo. As políticas sociais são incorporadas ao capítulo referente aos Direitos Humanos de Cidadania e o Estado é a esfera necessária de efetivação das mesmas.

Estas transformações da economia política do Estado no capitalismo pósguerra e o surgimento dos Estados de Bem-Estar possuem diversas leituras. O crescimento da militância operária comunista e social democrata, a formação dos partidos social-democratas e a expansão do socialismo, sob diferentes versões, convergindo para profundas reformas dos Estados capitalistas atingem o status quo da política europeia.

A ameaça dos operários europeus se tornarem comunistas revela a dimensão do conflito de classes existente na Europa e pressiona o Estado capitalista a prestar atenção à incorporação de reformas sociais capazes de diminuir o grau de atrito gerado pela luta da classe operária na crise econômica e social do período após a Segunda Guerra. Além do mais, a expansão eleitoral e o crescimento dos partidos social-democratas de países europeus como Suécia, Inglaterra, França, Holanda, Noruega e outros provoca um recuo e aceitação dos Estados por demandas sociais, econômicas e políticas que em outra época seriam impensáveis.

A este processo corresponderá o movimento posto em marcha por governos social-democratas em direção à política econômica formulada pelo economista inglês John Maynard Keynes, que levava ao redimensionamento do papel do Estado na economia e a uma nova compreensão do mercado entendido como uma instituição da sociedade capitalista que não poderia se autorregular. A ideia de Keynes era a de que um mercado liberado a suas próprias forças tendia a destruir a sociedade. A alternativa seria redefinir o papel do Estado enquanto acelerador e investidor de maneira a gerar emprego, trabalho e consumo. A política econômica passaria assim a se sustentar no desenvolvimento e na redistribuição da renda enquanto o mercado seria apenas complementar a este processo e não motor do mesmo.

Nesta concepção, as políticas sociais constituem um importante instrumento de política econômica na medida em que geram emprego e operam a distribuição de renda através da saúde, educação, moradia e políticas semelhantes que produzem bens públicos de consumo do trabalhador, complementando o salário e providenciando emprego. A política social se localiza no coração do Estado e, ao mesmo tempo que prolonga a existência do Estado capitalista, é geradora de conexões profundas entre o Estado e a Sociedade diferentemente de um liberalismo que propiciou o abismo entre ambos. 
As duas outras referências teóricas que considero de singular importância para compreender as políticas sociais nos Welfare States europeus são a formulação de Weber sobre as classes socais e o exercício da dominação no capitalismo; e as ideias de Polanyi sobre o papel do mercado e do Estado no capitalismo moderno.

De Weber, extraímos especialmente o método com o qual formula a sua teoria. A teoria opera através da construção de modelos gerados indutivamente. Isto significa a elaboração de categorias de análise criadas a partir da recorrência presente em configurações sociopolíticas ao longo da história social da humanidade no que se refere a comportamentos sociais - parentesco, religiosidade, valores -; formas de organização social; formas de organização política; tipos de organização; funções desempenhadas pelas organizações; condutas sociais esperadas; a construção conceitual que as informa e/ou uma combinação de categorias.

Diferentemente de Marx, para quem as classes sociais se definem pela propriedade (ou carência) dos meios de produção e pelas relações sociais de produção - no caso o modo de produção capitalista -, a teoria das classes sociais em Weber define as classes pelo conjunto de pessoas que ocupam posições similares na sociedade; ou seja, inicia o estudo das classes pela situação de classe que, como veremos adiante, diz respeito às posições diversas que os homens ocupam socialmente. As categorias a seguir iluminam o processo weberiano de formulação teórica e de criação de modelos de abordagem da sociedade. No caso nos referiremos apenas às sociedades do século XX, sem entrar em considerações históricas e na categoria estamento, correspondente às classes nas sociedades pré-capitalistas.

Assim,

Situação de classe: é o conjunto de probabilidades típicas (probabilidade de ter bens; de posição externa, de destino pessoal) que derivam da ordem econômica, da grandeza e natureza do poder de dispor (ou da carência) de bens e serviços e de utilizar estes para ter renda ou lucro.

Classe: todo grupo humano que se encontra numa determinada situação de classe.

Situações de classe e classe sempre se referem ao fato de existirem situações típicas de interesses iguais.

Tipos de Classe: classe proprietária é determinada pela diferença de propriedade. Há dois tipos de classe: positivamente privilegiadas correspondem àqueles que são remediados (de terra, escravos, instalações de trabalho) e credores e os negativamente privilegiados (servos, pobres, devedores). Entre ambos há classes médias, algumas das quais são lucrativas (empresários positivamente privilegiados e proletários negativamente privilegiados) e há classes médias que não são lucrativas (os camponeses, artesãos, empregados). A articulação das classes proprietárias puras não é dinâmica, não conduz necessariamente à luta de classes. 
Classe lucrativa: a situação de classe é determinada pela probabilidade (negativa ou positiva) de obter lucro, no mercado de bens e serviços. Classe lucrativa é uma situação de classe que implica em monopólio da produção de bens com vista ao lucro, influir na política econômica das associações (incluso políticas) para assegurar lucro. Estas se diferenciam também em positivamente privilegiadas (empresários, comerciantes, industriais, armadores, banqueiros, certos "liberais") e negativamente privilegiadas (trabalhadores qualificados, semiqualificados e não qualificados). Entre ambas também há classes médias (camponeses e artesãos independentes e frequentemente funcionários e trabalhadores altamente especializados).

Classe Social é a totalidade das situações de classe entre as quais é fácil um intercâmbio pessoal e entre situações, ocorrendo de modo típico. As classes sociais são: a) proletariado em seu conjunto; b) pequena burguesia; c) "intelligentzia" sem propriedade e "experts" profissionais; d) proprietários e privilegiados por educação.

Conclui-se que na concepção weberiana sobre as modernas sociedades capitalistas, há quatro classes sociais, diferentemente das duas classes antagônicas, capitalistas e operários, em Marx. Numa leitura controvertida de Weber se agregaria uma quinta classe (ou não), a burocracia, outorgando-se a esta um status diferenciado ao considerá-la enquanto um âmbito de estudos específicos que se denomina "sociologia da burocracia". Uma segunda vertente de pensamento é a que se refere à ordem política e ao Estado no capitalismo, que trabalha com idênticos princípios metodológicos e que Weber denomina de sociologia política. Assim,

Poder: a probabilidade de impor sua vontade a outros numa relação, ainda que contra a vontade alheia.

Dominação: Se refere ao poder com mandato determinado. A dominação pode ser tradicional, baseada na crença da legitimidade da autoridade que sempre existiu; carismática, que é também pessoal ainda que oposta à tradição e se sustenta na obediência a um líder. Finalmente a dominação legal que é a que sustenta o Estado Moderno.

O Estado moderno se caracteriza por se basear numa ordem legal, ter uma jurisdição compulsória sobre um território, possuir uma burocracia, ter o monopólio do uso legítimo da força. As regras são uniformizadas, legalmente criadas, em obediência às regras do direito formal. Tanto no que se refere à lei, como à burocracia. O tipo mais puro de dominação legal é a burocracia moderna.

\section{Associações de Dominação}

Há dois tipos de associações de dominação. A política, garantida pela força física (potencial) ou real, e o Estado que é o monopólio legítimo e continuado da coação física exercido pelo quadro administrativo. Mas esta forma de dominação do Estado não é suficiente se não existir dominação legal, ou seja, um sistema de 

regras aplicadas judicialmente e administrativamente a partir de princípios explícitos e válidos para todos os membros da sociedade.

Tanto no que se refere à lei como à burocracia, há atributos comuns no Estado moderno que são a calculabilidade, a previsibilidade, a certeza quanto aos procedimentos para alterações da lei e igualdade jurídica para os dominados. Observase, no que se refere à luta política na ordem legal, o papel das máquinas partidárias, o consumo eleitoral e a crescente burocratização que tendem a gerar uma autonomia burocrática na sociedade de massa.

Dominadores: superiores, eleitos ou aprovados por procedimentos padronizados e dedicados à manutenção da ordem legal. No Estado capitalista moderno, o dominador exerce a autoridade orientando-se por uma ordem impessoal, tendo limites formalmente definidos de mando. As autoridades são hierarquicamente ordenadas, permitindo, assim, um sistema de apelações. O quadro administrativo que aplica as regras não tem a posse dos meios de administração e produção. Observe-se, porém, que mesmo na forma mais pura de dominação legal (a burocracia ideal - típica), penetram fatores não sociais na escolha do "topo da pirâmide".

Dominados: obedecem como iguais à lei e não às pessoas que a implementam; obedecem enquanto cidadãos e nos limites do direito formal estatuído. A obe-diência não vai dirigida a uma pessoa, mas à ordem impessoal formalizada e posta em funcionamento por um quadro administrativo definido e questionável, por meio de "apelações".

As categorias weberianas trazem para o estudo do Estado capitalista moderno considerável riqueza. De uma parte, a ideia da complexificação das sociedades nas quais a oposição e a luta de classes não são tão claras nem inexoráveis como Marx observou no século XIX. Neste sentido, a formulação de políticas sociais no século XX expressa a luta da sociedade por mudar condições de exploração da força de trabalho e a vontade política dos governos do Welfare States em diminuir a brecha que separa a ambos, Estado e Sociedade, assim como aliviar as iniquidades geradas pelo mercado. A reconsideração do papel do Estado na sociedade contemporânea abriu espaços para que a sociedade se torne objeto direto de políticas estatais. De outra parte a sociologia política de Weber se debruça sobre dois momentos intrínsecos e conexos à existência do Estado. Referimo-nos à coação e à legitimação. Uma vez que coação e legitimação são faces de uma mesma moeda, o Estado vai se tornar terreno fértil para que direitos sociais de cidadania sejam encarnados nas nascentes políticas do Welfare State. Políticas sociais e de saúde geram mediações políticas entre o Estado e a sociedade, sob a forma de uma proteção social extensa. A sociologia política de Weber provê as categorias de análise e de compreensão das transformações sócio-históricas das instituições no exercício da dominação política e, consequentemente, da forma institucional Estado e sua estrutura jurídica no capitalismo contemporâneo.

Para finalizar a revisão dos autores clássicos selecionados como base de sustentação teórica para a análise de políticas sociais e de saúde, considerarei as ideias de Polanyi sobre o mercado na sociedade e no Estado moderno. Elas completam o 
circulo teórico compreensivo capaz de contribuir com uma metodologia/episteme à investigação das políticas sociais e de saúde.

Para Polanyi, a economia política e o conceito de classe surgiram com a ideia da harmonia e da autorregulação do mercado paralela à competição e ao conflito que o mercado trazia para o seio das sociedades em processo de desenvolvimento industrial capitalista. É a partir do choque entre os princípios organizadores do liberalismo econômico com a proteção social e o conflito de classes que estes princípios liberais originaram o que resultou a tragédia das sociedades em processo de industrialização. O abandono da antiga legislação de proteção social - poor laws, speenhamnland e outras - deu lugar à ideologia da supremacia do mercado, ocasionando o pauperismo e os conflitos de classes dos séculos XVIII e XIX.

A visão liberal era fortemente crítica da intervenção da ordem política sobre o mercado, mas toda a argumentação do autor mostra que sem essa intervenção os mercados livres não poderiam funcionar. Na medida em que os mercados não se autorregulam, sempre existiu, na prática, uma regulação externa ao mercado. Contrariamente ao que a teoria econômica liberal prescrevia - o laissez faire -, não existia alternativa para a realização do mercado que não fosse confiar ao Estado liberal, com seus novos poderes, órgãos e instrumentos para a garantia da propriedade privada, ao livre trânsito do capital e à permanente expansão dos mercados.

Enquanto a economia do laissez faire foi o produto da ação deliberada do Estado, as restrições subseqüentes ao laissez faire se iniciaram de maneira espontânea. O laissez faire foi planejado o planejamento não ( POLANYI,1980,p. 172).

Importante a observação de Polanyi: a intervenção sobre o mercado não foi planejada, ela se revelou espontânea e respondeu a uma necessidade pragmática do Estado de proteger o mercado dos seus efeitos deletérios, já que o mercado deixado a si mesmo tenderia à destruição da força de trabalho, das instituições da sociedade e dele mesmo.

Para Polanyi, à diferença de Marx, as instituições antecedem os modos de produção; a organização social e cultural é a base da civilização e a "catástrofe das comunidades sobrevém como resultado da ruptura rápida e violenta das instituições básicas da vida"(POLANYI,1980, p.214). As instituições são despedaçadas quando uma economia de mercado imposta a uma comunidade organizada de um modo completamente diferente não pode ser assimilada. Transformar o trabalho e a terra em mercadorias acaba com toda e qualquer instituição cultural organizada com base em outros cânones.

O trabalho não pode ser uma mercadoria. Separar o trabalho das outras atividades da vida e sujeitá-lo às leis do mercado significa para Polanyi destruir todas as formas orgânicas da existência e substituí-las por uma "organização atomista e individualista". A terra é um elemento da natureza entrelaçado às instituições do homem e que passa a ser objeto de comércio; exige-se dela um incremento da produção de alimentos e de matéria-prima para a indústria; se incrementa a produção dos territórios e colônias. Assim, a terra e sua produção se inserem no esquema do 

mercado autorregulável. A moeda que constituía mais um complemento de troca entre mercadorias, com a expansão da produção e do comércio passa a ser essencial e também necessária à produção de quantidades maiores de dinheiro. Grande dificuldade sobrevém com a necessidade de câmbios externos estáveis e com a introdução do padrão ouro. O dinheiro se torna o valor de troca de toda e qualquer mercadoria. Esta é a verdadeira essência do mercado. E como coloca Polanyi, a construção subjacente à economia clássica desde Ricardo, ainda antes de Marx, é que a determinação do valor de troca das mercadorias é dada pelo tempo de trabalho necessário expresso na mercadoria dinheiro; mas para acumular capital é preciso possuir dinheiro ou terra. Na medida em que o sistema de mercadoria internacional passa a ser o dinheiro não é mais possível uma economia de mercado separada da esfera política, do Estado. A introdução de uma política monetária exige a existência de um Banco Central, que é uma medida de política econômica/política monetária que somente o Estado pode gerar.

Conceitos, visões teóricas, percepção do mundo e alcance social e subjetivo conformam uma "biopolítica", à maneira foucaltiana:

A racionalidade governamental, nesse momento - estamos na época da razão de Estado - é a racionalidade do próprio soberano, a racionalidade daquele que pode dizer "eu o Estado".(..) o que é esse eu que refere a racionalidade do governo à sua própria racionalidade de soberano, maximizando seu próprio poder?(...) é a racionalidade dos governados que deve servir de princípio de regulagem para a racionalidade do governo. (...) Pode se dizer, de maneira global, geral, que todas as políticas nacionalistas, as políticas estatais, etc. vão ser políticas cujo princípio de racionalidade será indexado à racionalidade ou, digamos, em outras palavras, ao interesse, e à estratégia dos interesses do indivíduo soberano, ou do Estado, na medida em que constitui uma individualidade soberana. (...) E afinal de contas, o que é o marxismo senão a busca de um tipo de governamentalidade que será indexado, claro, a uma racionalidade que não se apresentará tanto como a racionalidade de uma história que se manifesta pouco a pouco como verdade? E é nisso que vocês vêem no mundo moderno, o mundo que nós conhecemos desde o século XIX, toda uma série de racionalidades governamentais que se acavala, se apóiam, se contestam, se combatem reciprocamente.(...) O que é a política, finalmente, senão ao mesmo tempo o jogo dessas diferentes artes de governar com seus diferentes indexadores e o debate que essas diferentes artes de governar suscitam? É ai, pareceme, que nasce a política (FOUCAULT, 2008, p. 4). 


\section{Os Estados de Bem-Estar}

Os estudos e debates sobre a origem e desenvolvimentos dos Welfare State nas sociedades capitalistas modernas são bastante abrangentes e comportam uma ampla produção dos campos do conhecimento econômico, sociológico e da ciência política.

A escolha do autor que trataremos a seguir, Gosta Esping-Andersen, obedece ao fato dele fazer uso do rigor teórico metodológico a respeito das questões consideradas no desenvolvimento deste trabalho e que constituem, no meu ponto de vista, o marco analítico mais adequado para a abordagem do Estado, das políticas sociais e das políticas de saúde combinado a um desenho de pesquisa comparada entre diversos Estados em países de capitalismo avançado. Isto nos permite compreender a feição econômica indissoluvelmente ligada à economia política, à estrutura social e à dimensão políticopartidária existente nos países objeto de pesquisa.

Neste sentido, a teoria acionada pelo autor para a compreensão dos modernos Welfare States se inscreve tanto na tradição teórica marxista quanto na perspectiva weberiana de observação das instituições estatais no que se refere à construção metodológica de modelos de política social. Os modelos, à luz do ensinamento weberiano, são construções analíticas, nunca se encontram em estado puro e constituem referências metodológicas criadas a partir de singularidades sociais recorrentes.

É necessário, antes de continuar com a discussão dos Welfare States, mencionar que o liberalismo trouxe à tona direitos dos indivíduos, aos quais nos referimos na discussão sobre Benjamim Constant, que se referem às liberdades civis e políticas, sendo os direitos civis os primeiros direitos usufruídos pela humanidade. Trata-se do exercício da liberdade de ir e vir, da liberdade de escolha de onde e em que trabalhar, da liberdade de difundir ideias e informação, mais tarde da liberdade de escolha política dos governantes: são estes os direitos civis e os direitos políticos. Aos últimos se somam tardiamente, já no século XX e após a Segunda Guerra, os direitos sociais que não se referem a indivíduos isolados, mas a todos os cidadãos pertencentes a uma sociedade nacional, ou seja, a um mesmo Estado, território político delimitado por fronteiras geográfico-políticas comuns. Estes direitos sociais de cidadania definem a distribuição social universal de bens públicos, educação, saúde, moradia, saneamento, por meio das políticas sociais e têm como contraparte a obrigação do Estado na distribuição destes bens para todos os cidadãos (MARSHALL 1969).

O ponto de partida para o autor é se os Welfare States que se estabelecem sobre os direitos sociais de cidadania poderiam transformar a sociedade capitalista ou se a distribuição de bens de consumo social pelo Estado capitalista poderia acabar com a distinção de classes existente nestas sociedades. Relacionada a esta última questão coloca-se o desafio de compreender quais são as forças que estão na base do desenvolvimento do Welfare State. Uma primeira constatação é que os economistas políticos clássicos, sejam eles liberais, conservadores ou marxistas, se preocupavam com a relação possível entre capitalismo e bem estar social. Como compatibilizar questões per se opostas: mercado (propriedade) e Estado (democracia)? Para o liberalismo clássico, assim como para a versão "neo" reeditada nos anos 1980 do século XX, o mercado é a forma econômica mais apropriada para abolir as classes sociais no capitalismo. 
ReVISth Em Pauta

Ao se referir aos economistas clássicos, Esping Andersen, diferentemente dos economistas neoliberais do presente, afirma que:

A adesão entusiástica deles ao capitalismo de mercado pode parecer injustificada hoje. Mas não devemos esquecer que a realidade da qual falavam era de um Estado que preservava privilégios absolutistas, protecionismo mercantilista e corrupção por toda parte (ESPING-ANDERSEN, 1991, p. 10).

Os conservadores, pelo contrário, defendiam a volta ao Estado monárquico. Para eles as diferenças de classes eram intrínsecas à sociedade e naturais, mas estas diferenças não precisavam vir acompanhadas dos conflitos de classes, tal como aconteceu na Revolução Francesa. Era necessário eliminar o conflito e para isto deviam-se implementar políticas de bem-estar de modo a garantir a harmonia entre as classes, a lealdade às hierarquias e a ordem no trabalho para o bom desenvolvimento da produção. O Estado ideal para os conservadores era aquele que perpetuasse o absolutismo, já que este era a melhor garantia de um capitalismo sem luta de classes. O Estado absoluto acabaria defendendo a classe proprietária sem a luta de classes e harmonizando o bem do Estado, da comunidade e do indivíduo.

Para a economia política marxista, toda e qualquer sociedade deve ser examinada a partir das relações sociais de produção nela estabelecidas. Para Marx, após as sociedades da comunalidade da terra, a organização da sociedade levou sempre à formação de ordens diferentes e opostas entre patrícios e escravos, senhores e servos, burguesia e proletariado e, nesta última forma, própria da sociedade capitalista, o Estado é apenas a forma política do exercício da dominação da classe social da burguesia sobre a classe dos trabalhadores. A burguesia no capitalismo industrial não apenas estabelece a dominação de classes por meio da modalidade dominante das trocas econômicas no mercado, como também exerce a direção do governo.

De fato, observa-se que no debate do século XX, o partido social-democracia, já como corrente política dissidente do Partido Comunista, defende a democracia parlamentar como a forma de governo mais apropriada à incorporação de reformas sociais para assim atenuar as desigualdades sociais produzidas pelo capitalismo. A ideia de democracias sensíveis a minorar os efeitos deletérios do capitalismo sustentava-se, de uma parte, na necessidade de trabalhadores com recursos sociais, educação, saúde, condições dignas de vida, capazes de participar na sociedade e na política como cidadãos socialistas. De outra, em uma concepção não só emancipatória da política social, mas também em sua importância na promoção das forças produtivas no capitalismo. Como afirma Esping Andersen, 1990:

O modelo social-democrata é, então, o pai de uma das principais hipóteses do debate contemporâneo sobre o Welfare State: a mobilização de classe no sistema parlamentar é um meio para a realização dos ideais socialistas de igualdade, justiça, liberdade e solidariedade. (ESPING-ANDERSEN, 1991, p. 12). 
Munido destes instrumentos conceituais da política econômica clássica e com a aspiração de remodelá-los à luz das mudanças e da produção teórica sobre o tema, ocorridas no mundo dos finais do século XX, o autor define um marco teórico conceitual que estabelece modelos comparativos de análise dos Welfare States em países de capitalismo avançado.

No campo dos estudos sobre o Welfare State duas abordagens dominam as explicações destes tipos de estado desde a segunda metade do século XX. Uma enfatiza o exame das estruturas e sistemas globais e outra, as instituições e atores.

A teoria estruturalista e de sistemas globais procura compreender a lógica do desenvolvimento. Predomina a preocupação em encontrar semelhanças, ou seja, as regularidades e não as diferenças entre as nações. "O fato de serem industrializadas ou capitalistas sobrepõe-se a variações culturais ou diferenças nas relações de poder" (ESPING-ANDERSEN, 1991, p. 13).

Outra característica é que interpretam ocorrências como sendo requisitos funcionais. Ou seja, na medida em que são identificadas ocorrências, entende-se que estas são necessárias e/ou funcionais e sem elas o WS não seria possível. Uma é função da outra e vice-versa. Referem-se também à existência de leis do movimento como se houvesse um ordenamento sequencial nas transformações sociais.

Para o autor, o novo estruturalismo marxista é bastante similar. Abandonando a teoria clássica que coloca grande ênfase na ação política, a "lógica do capitalismo" se apóia na ideia de que o poder é estrutural (O'Connor, 1973; Poulantzas, 1977; Block, 1977).

As abordagens de cunho institucional residem, de uma parte, no legado dos teóricos do liberalismo clássico, basicamente o divórcio entre política e economia - defesa dos mercados contra a intrusão da política. Seus expoentes são basicamente antidemocráticos; e de outra, em Polanyi (1944) insistem na ideia de que qualquer esforço para isolar a economia das instituições sociais e políticas destruiria a sociedade humana. Polanyi vê a política social como pré-condição para a reintegração da economia social.

A relação entre democracia e WS na abordagem institucionalista tem sido bastante discutida. Em sua formulação clássica, defendia-se que as maiorias favoreceriam a distribuição social para compensar os riscos do mercado. A democracia seria entendida como uma instituição que não pode resistir às demandas da maioria. Nas suas formulações modernas têm muitas variantes a exemplo da teoria da cidadania, das teorias pluralistas e outras (Marshall, 1950; Bendix, 1964; Rokkan, 1970). Mas as primeiras iniciativas do WS foram desenvolvidas sem democracia como noscasos da França e Alemanha (Sckopol e Amenta, 1986). Inversamente, nas democracias que surgem mais cedo o WS é mais tardio como nos Estados Unidos, Austrália e Suíça. Para Esping-Andersen, esta contradição aparente só pode ser explicada com referências às classes e à estrutura social. Para o autor, a teoria da classe social enquanto agente político se distingue da análise estruturalista, que outorga um status central às classes sociais na sociedade capitalista, e da abordagem institucional, que coloca a ênfase nas instituições ao defender a tese da mobilização das classes baseada na concepção da economia política social-democrata. 
Os direitos sociais, seguro-desemprego, igualdade e erradicação da pobreza que um Welfare State universalista busca são pré-requisitos necessários para a força e unidade exigidas para a mobilização coletiva de poder. (ESPING-ANDERSEN, 1991, p. 28)

Os Estados de Bem-Estar se caracterizam pela presença de três princípios centrais: a cidadania social; o direito social possui o mesmo status legal e prático dos direitos de propriedade; e a desmercadorização do status das pessoas.

O conceito de desmercadorização é formulado pelo autor e se refere à prestação de serviços, da parte do Estado, como assunto de direito e ao fato de uma pessoa poder viver dignamente sem depender do mercado. Diferentemente, na ausência de desmercadorização se os subsídios do Estado são mínimos e acompanhados de estigma, o sistema de ajuda empurra as pessoas para o mercado. De modo geral, os sistemas de seguridade social foram desenhados para maximizar a participação das pessoas no mercado. Os países escandinavos são mais desmercadorizados e os anglo-saxões menos. As variações nos direitos sociais e na estratificação formam ordenamentos diferentes entre Estado, mercado e famílias.

Com estas categorias de análise, trata-se de examinar os subsídios da pesquisa comparativa na compreensão do desenvolvimento do Welfare State em países de capitalismo avançado. $\mathrm{O}$ autor conclui sobre a existência de três modelos de Welfare State: um modelo residual/liberal, um modelo conservador/corporativista e um institucional/social-democrata. No primeiro, predomina a ajuda frente à comprovação da necessidade. No segundo, a ideia da conservação do status; o Estado intervém quando a família falha em evitar que os indivíduos caiam na pobreza e marginalidade social. O terceiro modelo se caracteriza pelo universalismo e a desmercadorização que se estende às novas classes médias. Promove igualdade em patamares mais elevados e se compromete com uma pesada carga de serviços sociais.

Se a tipologia de Esping Andersen tem por núcleo tipos de Estado e política, estudos complementares sobre política social, dentre eles os de Habermas, Rosanvallon e Castel permitem vislumbrar o ângulo da esfera pública. Aqui, o conceito-chave é cidadania e o processo básico é a comunicação racional que envolve valores e normas, ou seja, o debate em torno do que cabe a governantes e legisladores fazer. Finalmente o valor solidariedade, ao qual as Ciências Sociais retornaram recentemente, configura um novo parâmetro analítico para se abordar políticas sociais específicas em contextos de Estados com formação e organização diversa à do Welfare State.

\section{A crise dos Estados de Bem-Estar e as políticas sociais e de saúde}

A abordagem da crise tem enfoques bastante diferentes. O trabalho envolverá uma leitura focada na análise da globalização econômica e na onda política neoliberal que se extendeu pelos Welfare States desenvolvidos da Europa, Canadá e os EUA, induzindo mudanças políticas e econômicas que iniciam com o primeiro governo neoliberal na Inglaterra da primeira ministra Margareth Thatcher, nos anos 
80. Discutiremos o processo de expansão desta crise nos anos 1990, sua chegada ao Brasil e a sua incidência no campo da saúde coletiva.

Um primeiro aspecto a destacar é a influência da globalização econômica e do poder financeiro no capitalismo dos finais do século passado, fundamentalmente produtivos, na passagem de economias industriais para economias de serviços. Os resultados foram importantes perdas de fontes de trabalho (GERSCHMAN, 2005).

Ao desemprego que estas mudanças ocasionaram se soma o desemprego que as economias industriais capitalistas, em processo de alta tecnificação e robótica, acrescentaram, ao expulsar mão de obra intensiva da indústria. Trata-se de questão central para o desenvolvimento dos Welfare States, se considerarmos a importância que o pleno emprego teve no modelo econômico keynesiano, sobre o qual se sustentou a economia política dos Welfare States europeus.

Pierson (2001) sustenta que as mudanças econômicas da manufatura para os serviços, antes de expressar disrupção no emprego, acusam mudanças na força de trabalho para atividades em que melhorias de produtividade são mais limitadas. O resultado acaba sendo um crescimento econômico lento que gera problemas fiscais para os WS maduros. Trata-se de um aspecto a ser considerado no conjunto das transformações "pós-industriais" que produzem fortes pressões sobre o WS no que se refere às estruturas de proteção das famílias e da população idosa. De todo modo, quaisquer que sejam os efeitos da globalização, estes são intensamente mediatizados pelos arranjos domésticos, o que faz com que não possam se esperar convergências nas políticas sociais nacionais.

Este ponto de vista é compartilhado por vários analistas do WS, que consideram que as instituições nacionais têm um papel crucial sobre os efeitos que emanam da globalização econômica. Cabe mencionar que enfoques como o de Pierson e outros autores são bastante frequentes nos estudos sobre o WS e estão baseados na escola teórica do institucionalismo histórico. Nesta abordagem, as instituições estruturam as situações em que os atores se encontram, alterando suas estratégias e metas; intermedeiam relações de cooperação e conflito; estruturam as situações políticas e deixam suas marcas nas consequências políticas. As instituições definem as "regras do jogo". A aprovação de uma lei, por exemplo, exige que tenha havido uma sucessão de votos favoráveis em todas as instâncias de decisão. Assim, a sorte de uma proposta legislativa, como a que se refere a um sistema nacional de saúde, depende do número e da localização de "oportunidades de veto" distribuídas ao longo dessa cadeia (IMMERGUT, 1992).

O objetivo central do institucionalismo histórico é a construção de uma teoria de médio alcance que estabeleça uma ponte entre análises centradas no Estado e na sociedade, tendo como foco variáveis de nível intermediário para dar conta da variação histórica e conjuntural dos fenômenos estudados. No nível intermediário, as grandes estruturas são mediadas pelas instituições (MARQUES, 1997). O institucionalismo histórico, enquanto metodologia de pesquisa social, é um instrumento importante para a elaboração de categorias de análise que estabeleçam mediações compreensivas e elos significativos, entre as teorias clássicas sobre o Estado, acima evocadas, e aquelas que buscam compreender os Welfare States a partir do estudo das políticas sociais e sua relação com os direitos de cidadania no Estado capitalista. 
Um segundo aspecto se refere ao novo papel atribuído ao Estado - o da não interferência no livre desenvolvimento do mercado - e às medidas de política econômica que adequam-no a este propósito: as restrições fiscais, dentre elas os cortes e o desfinanciamento de políticas sociais; a desregulação do trabalho; a privatização de empresas nacionais; a tendência à privatização da previdência, saúde e educação; e finalmente a implementação de políticas focais direcionadas aos novos pobres.

Dos modelos da seguridade social sustentados no direito à cidadania social e no papel central do Estado enquanto provedor e regulador de serviços sociais em saúde, educação, trabalho e outros, caminha-se para o livre exercício do mercado. O Estado perde a sua função reguladora e de intervenção tanto no mercado quanto na vida social. A sociedade passa a ser vista como um aglomerado de "indivíduos livres" e, portanto, capazes de adquirir no mercado os bens necessários para a satisfação das suas necessidades ou, ao contrário, carecer dos mesmos.

O Estado social desaparece soterrado pelo Estado que se torna, sob a ideologia neoliberal, fiador do mercado elevado à condição de Deus ex machina e munido das ferramentas jurídicas necessárias a seu novo papel de guardião e restaurador do livre mercado, tal como requerido pela era do capitalismo financeiro globalizado. Neste papel, o Estado renasce das cinzas sociais das sociedades da abundância para se erigir como o Estado liberto e separado da sociedade e cujas funções se limitam a garantir a propriedade privada, a segurança do capital, a ordem e o controle social da sociedade do "não trabalho", do refugo resultante da plenitude do mercado. Tão nobre papel traz à cena política vestígios daquele Estado nas origens da sociedade industrial capitalista.

Assim como o pauperismo do século XIX estava inserido no coração da dinâmica da primeira industrialização, também a precarização do trabalho é um processo central, comandado pelas novas exigências tecno-econômicas da evolução do capitalismo moderno. Realmente, há aí uma razão para levantar uma "nova questão social" que para espanto dos contemporâneos, tem a mesma amplitude e a mesma centralidade da questão suscitada pelo pauperismo do século XIX (Castel, 2001, p. 484).

Esta questão tão instigante de Castel traz à cena, mais uma vez, indagações a respeito das relações Estado/Sociedade, Público/Privado e sobre o papel das instituições sociais e políticas no equacionamento de políticas sociais, especialmente a política de saúde perante o papel sobredimensionado do mercado.

A última parte do trabalho se refere a estudos da política de saúde comparada em contextos nacionais diversos elaborados mediante instrumentos de pesquisa baseados sobre o andaime teórico conceitual formulado neste artigo.

Teoria e Pesquisa em Políticas de Saúde

Os resultados de pesquisa relativos às políticas de saúde reproduzidos a seguir, nos Welfare States desenvolvidos e no Brasil, permitem identificar as dinâmicas 

que parecem monoliticamente estatais/governamentais são passíveis de transformações oriundas do campo institucional, político e da mobilização societária.

O trabalho de Giaimo (2001) se valeu de uma perspectiva de pesquisa de política comparada de instituições estatais da seguridade social, modalidades do sistema político e exercício da política na Inglaterra, Alemanha e Estados Unidos. Perante a diretiva da contenção de custos-ajuste fiscal, a pesquisa procurou observar os três sistemas com o intuito de explorar se, a despeito da sua variação institucional estatal, política e societária, estes países convergiram para uma resposta comum ou se as diferenças entre eles moldaram as reformas neoliberais dentro de padrões específicos, e quais seriam estes padrões.

Os resultados são bastante interessantes e mostraram como os objetivos da "reforma neoliberal do Estado", guiada pela contenção de custos, eficiência e equidade foram direcionados por caminhos bem diferentes. Inglaterra e Alemanha conseguiram diminuir os custos do Welfare sem acabar com os princípios do acesso universal à saúde e sem exigir dos membros mais vulneráveis da sociedade suportar uma divisão desproporcional dos custos do ajuste. Colocando estes países numa escala de ajuste fiscal, a Inglaterra teve o melhor desempenho, a Alemanha representa um caso intermediário e os Estados Unidos gastaram mais do que a Inglaterra e, pior ainda, produziram um crescimento das iniquidades existentes. Apenas no ano 2000 houve uma redução dos gastos, acompanhada da piora do acesso para os mais doentes e mais pobres.

A autora atribui estes diferentes resultados à ação e às preferências dos pagadores - quem financia o sistema de saúde - e do papel do Estado em cada país. As estratégias de contenção de custos se tornaram inimigas da equidade e solidariedade, dependendo do sistema de cuidados de saúde nos quais estas estratégias foram gestadas. Em suma, os atores estatais tiveram diferentes papéis na governança do sistema de saúde, que podem ser atribuídas às expectativas e à capacidade para assegurar que os projetos de contenção de custos fossem ou não compatíveis com a equidade.

Ao lado das políticas contemporâneas de reformas dos sistemas de saúde houve uma grande campanha de descrédito dos Welfare States. Governantes e empregadores se tornaram bastante apreensivos sobre os efeitos dos WS na competitividade econômica dos Estados nacionais. Mas as razões para a elevação dos preços são comuns a todos os países e estão relacionadas aos seguintes aspectos: 1) O setor da saúde é um campo fértil para inovações tecnológicas que podem prolongar a vida com despesas consideráveis; 2) A população dos países ocidentais está envelhecendo com consequências diretas nos cuidados de saúde; 3) O setor da saúde é gerador de enorme quantidade de emprego no setor de serviços, empregos que tendem a ser de trabalho intensivo e baixa produtividade em relação ao trabalho industrial que substituem (PIERSON, 2001).

Algumas das causas da inflação dos sistemas de saúde também repousam no desenho específico em cada país. Sistemas de saúde de múltiplas seguradoras tendem a ter altos custos administrativos mais do que sistemas de um único pagador como é o caso dos sistemas públicos de saúde. Ainda que a data seja diferente de país para país, desde 1980 o Welfare State se tornou inseparável da questão nacional e 

do nível de ajuste das empresas com uma mais integrada e competitiva economia mundial. Neste debate, o WS aparece como um impedimento para o ajuste econômico e a solução que se deu, no contexto político econômico do neoliberalismo, foi reduzir sua extensão em vários sentidos.

Para explicar resultados diferentes é necessário conhecer o que os financiadores fizeram, o que eles desejavam das reformas dos sistemas de saúde e o que foram capazes de executar. Em cada país os sistemas de saúde designaram diferentes atores como pagadores (financiadores) e provedores (produtores de serviços) com diferentes capacidades para realizar o objetivo de contenção de custos. Assim, no Sistema Nacional de Saúde inglês, o Estado é responsável por financiar e providenciar serviços de saúde. Na Alemanha, empregadores e empregados têm igual responsabilidade para financiar e administrar o Seguro Nacional de Saúde. Considerando que ambos, empregadores e sindicatos, são partes indissolúveis nestes arranjos, fica difícil para cada parte agir unilateralmente contra o outro. Nos Estados Unidos, os empregadores são os principais participantes e pagadores na política de reforma do sistema de saúde. Isto se deve a que a maioria dos americanos compra seu seguro de saúde em companhias limitadoras de benefícios. Acrescentando ao sistema de saúde a arena política, esta oferece aos pagadores uma alternativa ou canal de influência complementar sobre o curso da reforma do sistema de saúde. Na Inglaterra, quem paga impostos (a sociedade) tem duas formas de exercer influência: o exercício do voto e a atividade dos membros do parlamento que regularmente interpelam o governo sobre a performance do National Health Service (NHS). Na Alemanha, empregadores e empregados criaram partidos políticos que advogam seus pontos de vista. O federalismo, também, por vezes provê meios adicionais de influência aos atores do sistema de cuidados de saúde. Nos Estados Unidos, a fragmentação do sistema político propicia aos empregadores amplas oportunidades de exercer "pontos de veto".

Os programas universais são os mais redistributivos dos programas de seguridade social, criando amplas solidariedades que acompanham a equidade e protegem os mais desprotegidos. Os sistemas universais na Inglaterra e na Alemanha equacionaram equidade com igualdade. A institucionalização da conduta de dividir o risco através da seguridade social reforça valores de compartilhamento e comunitarismo na sociedade. Em contraste, nos Estados Unidos, a natureza privada e voluntária da condição de empregado estabelece o limite dos benefícios, sistema que produz profundas iniquidades.

$\mathrm{Na}$ experiência brasileira ${ }^{3}$, diferentemente dos países europeus, o setor privado da saúde antecede historicamente a formulação do Sistema Único de Saúde (SUS). Ao longo da história, diversos arranjos de financiamento e provisão de serviços de saúde foram propostos para dar conta da saúde pública e privada, erguendo as bases para um sistema de saúde extremamente fragmentado (MEDICI, 2002). Os setores público e privado dividiram o financiamento público e a titularidade do

${ }_{3}^{3}$ Gershman, S., Políticas Comparadas de Saúde Suplementar no Brasil no Contexto de Sistema Públicos de Saúde: União Européia e Brasil, ABRASCO, vol. 13, n. 5, set/out 2008. 

dinâmica do capitalismo começa a consolidar o complexo médico-industrial da saúde, contribuindo para um enorme crescimento dos custos da assistência médica (CORDEIRO, 1984), transformando-a crescentemente em um empreendimento dependente de capital.

Com a consolidação de um padrão de empresariamento privado da saúde inicia-se uma disputa por segmentos de clientela e especializações, com tentativa do setor privado de preservar suas fontes públicas de financiamento mediante uma presença marcante e cada vez mais organizada nas arenas decisórias (LABRA, 1993; COSTA, 1998 apud GERSCHMAN \& BORGES, 2006) e cada vez mais significativa no mercado.

De fato, preservou-se o sistema de contratação e convênios com o setor privado, do antigo Instituto Nacional do Ministério da Previdência Social (INAMPS), cuja diretriz política era a expansão de serviços e coberturas e a consolidação da iniciativa privada em saúde, que aufere os benefícios da contratação para prestação direta de serviços de saúde financiados pelo setor público.

O sistema público se precipita em franca deterioração que se expressa em sérios problemas de estrutura, aparelhamento e instalações e enormes dificuldades no acesso; ao mesmo tempo em que o setor privado cresce sem nenhum tipo de controle e em aberta sobreposição aos serviços de atenção à saúde do SUS.

As relações pautadas historicamente pelas instituições públicas e privadas na saúde constrangem ou limitam uma nova institucionalidade do setor público e dos serviços de saúde nas instâncias federativas, estaduais e municipais que compõem o SUS.

A dimensão do problema que se coloca é a formulação de políticas regulatórias para a esfera de planos privados de saúde, setor definido constitucionalmente como complementar ao SUS, no contexto do sistema de saúde tal como definido pelo artigo 198 da Constituição como sendo de caráter público, único, universal e descentralizado. Problema que se agrava se considerarmos que o parque hospitalar privado não foi criado como "complementar" ao sistema público, mas fundamentalmente para dar conta de um "nicho de mercado" em que o setor público era deficitário. Cabe acrescentar que o setor filantrópico também cresceu consideravelmente sobre a base de estender seus negócios, atendendo à clientela de seguros privados de saúde (UGÁ et alli, 2006).

Ainda que as políticas de saúde, produto do papel dos movimentos sociais e sanitário atuantes na conjuntura política da democratização do país se originem em princípios similares aos princípios da seguridade social dos países europeus, as aproximações são pequenas, se considerarmos as trajetórias histórico-institucionais, o frágil papel do Estado na esfera pública e o papel dos interesses privados no sistema público de saúde.

O Brasil implementou um sistema de saúde público e universal tardio, numa conjuntura internacional adversa, seja no que se refere ao papel do Estado na provisão de benefícios sociais universais resultantes de direitos de cidadania social, seja em políticas econômicas direcionadas ao desenvolvimento nacional. Estas substituidas pela globalização econômica, pela concepção neoliberal de política eco- 

nômica e pela não interferência do Estado no mercado, à exceção das salva-guardas necessárias a sua otimização.

Considerando as diferenças presentes nas duas experiências, pode-se identificar semelhanças que a conjuntura dos anos 1990 trouxe para ambas, se devidamente relativizadas e/ou equacionadas as consequências resultantes.

(...) a diminuição de leitos trouxe sérios problemas no acesso a serviços hospitalares; já que não houve uma racionalização na distribuição destes serviços em regiões distantes e isoladas dos grandes centros urbanos. Permanecem e cresceram para alguns municípios e estados as iniquidades no acesso, especialmente na média e alta complexidade. As listas de espera que são importantes ferramentas para a cobertura universal e contribuem para melhorar o acesso são raramente implementadas; apenas existem listas de espera para procedimentos de alta complexidade tais como transplantes. As barreiras de acesso relativas à coexistência de seguros privados dando cobertura aos mesmos serviços do SUS, sobretudo no que se refere à atenção ambulatorial constitui grave problema para o SUS e para o usuário que paga ao seguro por um serviço em que, as vezes, é coberto pelo próprio sistema público (GERSCHMAN, 2008, p. 1132).

Mas, enquanto nos Welfare States europeus, o neoliberalismo não significou importantes retrocessos na defesa da garantia fundamental dos direitos sociais de saúde, no Brasil o princípio estruturante da seguridade social que permaneceu foi apenas o de enfrentamento das enormes desigualdades de saúde por meio de programas focalizados na atenção primária, tais como o programa de saúde da família, de atenção a gestantes e crianças e outros similares.

\section{Considerações finais}

A ideia deste trabalho surgiu como uma maneira de estruturar um conhecimento teórico sobre o qual venho trabalhando faz longo tempo. A esta altura cabe reiterar que as Ciências Sociais estão incorporadas à Saúde Coletiva não para informar, mas para alimentar um projeto que se reponha na direção contrária a um mundo que é permanente gerador de pobreza, desigualdades em saúde, doenças e todo tipo de carências sociais. A contribuição das Ciências Sociais para a saúde é a reflexão a respeito da vida e da condição humana e o interesse por compreender a sua incorporação disciplinar ao campo das políticas de saúde. Neste sentido, ambas se modificam pela existência de uma na outra, e modificadas formulam uma complexidade explicativa alternativa à descrição das políticas de saúde sob uma perspectiva operacional. Decretos, leis; documentos ministeriais; administração e gestão; recursos financeiros e humanos; dificuldades na implementação e avaliação da efetividade a partir de relatos e levantamento de resultados numéricos, como se estes procedimentos falassem por si mesmos ou como se os números levassem impresso o significado daquilo que medem e dizem apenas, com respeito aos aspectos relativos à administração de políticas de saúde. 


\section{REVISTA Em Pauta}

Volume 6 - Número 23 - Julho de 2009

\} Economia, Sociedade e Política na Construção de um Campo do Conhecimento: a Saúde Coletiva no Brasil - GERSCHMAN, S. \}

A compreensão do sentido dos levantamentos de pesquisa, tais como entrevistas, documentos e/ou observações quantitativas, enquanto não for entendido no interior de unidades de sentido, pouco poderá nos dizer sobre a realidade e a intervenção sobre ela. A reflexão teórico-conceitual e metodológica capaz de compreender as políticas em curso e formular as mediações necessárias para a construção de pesquisa mais avançada na área torna-se essencial para agir no complexo mundo em que vivemos. 


\section{REFERÊNCIAS BIBLIOGRÁFICAS}

AROUCA, A. S. S., O dilema preventivista: contribuição para a compreensão e crítica da medicina preventiva. Tese de doutorado. Campinas: UNICAMP, 1975, mmeo. BENDIX, R. Nation - building and cirizenship. New York: John Wiley and Sons, 1964.

BENJAMIN CONSTANT. Princípios políticos constitucionais. Org. Aurelio Wander Bastos. Rio de Janeiro: Liber Juri, 1989. Edição incompleta.

BERLINGUER, G. La saluute nelle fabriche. Roma: Donato Editore, 1975.

BRAGA, José Carlos de S. e PAULA, Sérgio Goés de. Saúde e Previdência. São PauIo: Cebes, Hucitec, 1981.

BLOCK, F. "Posindustrial development and the obsolence of economic Categories". Politics and Society, m 14(1). Madison: s/ed, 1985.

BOBBIO, N. Teoria geral da política. São Paulo: Editora Campus, 2000.

CASTEL R. As metamorfoses da questão social; uma crônica do salário. Petrópolis: Editora Vozes, 1998.

CORDEIRO, H. A. As empresas médicas. Rio de Janeiro: Edições Graal, 1984.

COSTA, N. R. Políticas públicas, justiça redistributiva e inovação: saúde e saneamento. São Paulo: Hucitec, 1998.

DONANGELO, M.C. Medicina e sociedade: o médico e seu mercado de trabalho. São Paulo: Pioneira, 1975.

ESPING-ANDERSEN G. The three worlds of welfare capitalism. Great Britain: Princeton University, 1991.

FLEURY, T. S. M. Assistência médica previdenciária: evolução e crise de uma política social. Tese de mestrado. Rio de Janeiro: IUPERJ, 1979. mmeo.

FOUCAULT, M. Nascimento da biopolítica; curso dado no Collège de France (19781070), São Paulo: Ed. Martins Fontes, 2008.

GARCIA, J. C. La articulación de la medicina y de la educación en la estructura social. Washington: OPS, 1974. mmeo.

GENTILE DE MELLO, C. Coleção de artigos, Folha de São Paulo. São Paulo: Folha de São Paulo, 1977, 1978.

GERSCHMAN, S. "Democracia, políticas sociais e globalização: relações em revisão". In: GESRCHMAN, S., \& WERNECK, M.,L. A Miragem da Pós-Modernidade. Rio de Janeiro: Ed. FIOCRUZ, 2003.

GERSCHMAN, S. \& BORGES, A.dos S. "O sistema único de saúde, como desdobramento das políticas de saúde do século XX". Revista Brasileira Ciências Sociais, V. 21, N. 61, São Paulo: ANPOCS, junho 2006.

GIAIMO S. "Who pays for health Ccare reform?" In: PIERSON P. The new politics of the Welfare States. Nova York: Oxford University Press, 2001.

IMMERGUT E. M., Health politics interests and institutions in Western Europe. Cambridge: University Press, 1002.

JAMES MILL. "Essays on government". In: JACK LIDELY e JOHN REES(Eds.) Utilitarian Logic and Politics. Londres: Oxford Clarendom Press, 1978.

LABRA, M.E. "Associativismo no setor saúde brasileiro e organizações de interesse do empresariado médico". Physis-Revista de Saúde Coletiva 3(2). Rio de Janeiro: IMS/UERJ, 1993. p.193-225. 
LUZ, M. T. Natural, racional, social: razão médica e racionalidade científica moderna. Rio de Janeiro: Campus, 1988.

MARQUES E. C. "Notas críticas à literatura sobre Estado, Políticas Estatais e Atores Políticos". Revista Brasileira de Informação Bibliográfica em Ciências Sociais. Rio de Janeiro: ANPOCS, 1997.

MARSHALL, T. H. Cidadania, classe social e status. Rio de Janeiro: Zahar, 1967. MARX, K. e ENGELS F. Manifesto do Partido Comunista. Moscou: Ed. Progresso, 1987.

MEDICI A. C. Financing health policies in Brazil: achievements, challenges and proposals. Sustainable Development Technical Department Papers Series. Washington: Inter-American Development Bank, 2002.

O'CONNOR. The fiscal crise of the State. New York: St.Martin's Press, 1973.

PIERSON, P. The new politics of the Welfare States. Nova York: Oxford University Press, 2001.

POLANYI, K. A grande transformação: as origens da nossa época. Rio de Janeiro: Ed. Campus, 1980.

POULANTZAS, N. O Estado, o poder e o socialismo. Rio de Janeiro: Graal, 1980. ROKKAN, S. Citizens, elections, parties. Oslo: Universitetsforlaget, 1970.

WEBER M. Economia y sociedade. México-Buenos Aires: Fondo de Cultura Económica, 1964, Volumen I.

Weber M., Economia y Sociedade. México-Buenos Aires: Fondo de Cultura Económica, 1964, Volumen II.

UGÁ, M.A.D.; LIMA. L.S.; PORTELA, M.C.; MURAt, V.M.; GERSCHMAN S. "Estudo dos prestadores hospitalares frente às práticas de micro-regulação das operadoras de planos de saúde". Relatório de pesquisa. Rio de Janeiro: ANS/ENSP, 2007. mimeo.

Recebido em 20 de abril de 2009.

Aceito para publicação em 29 de maio de 2009. 